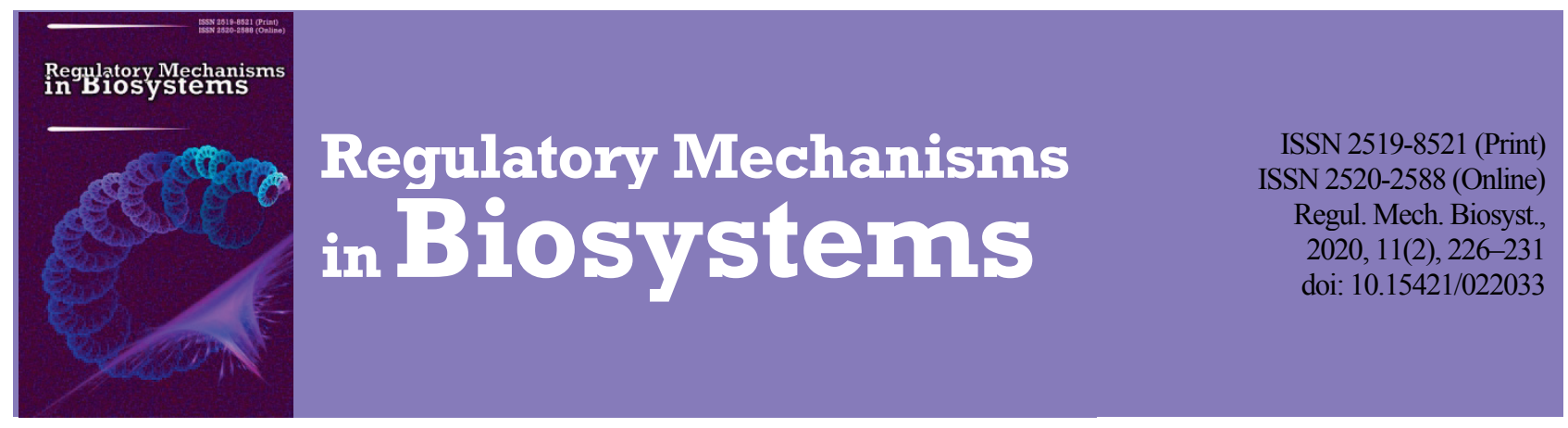

\title{
Analysis of the treatment regimen efficacy for columnaris disease in Pterophyllum scalare
}

\author{
I. V. Lavrinenko, L. V. Shulga, O. O. Peredera, I. A. Zhernosik \\ Poltava State Agrarian Academy, Poltava, Ukraine
}

Article info

Received 05.04.2020

Received in revised form 01.05 .2020

Accepted 02.05.2020

Poltava State

Agrarian Academy,

Skovoroda st., 1/3,

Poltava, 36000, Ukraine.

Tel.: +38-099-163-37-13.

E-mail:ua151@ukr.net

\begin{abstract}
Lavrinenko, I. V., Shulga, L. V., Peredera, O. O., \& Zhernosik, I. A. (2020). Analysis of the treatment regimen efficacy for columnaris disease in Pterophyllum scalare. Regulatory Mechanisms in Biosystems, 11(2), 226-231. doi:10.15421/022033

The article presents the results of studies on the treatment scheme efficacy for columnaris in Pterophyllum scalare, common under private aquarium husbandry conditions. To establish the diagnosis, the clinical features of the diseased fish, pathological and anatomical changes and the results of microscopic and microbiological studies were taken into account. Separate chemical and microbiological parameters of aquarium water were also studied. It was established that fish disease developed against the background of adverse changes in the chemical composition and microbiocenosis of aquarium water. High alkalinity and excess of phosphates compared to the norm provoked accumulation of opportunistic microbiota, resulting in a balance disorder in the parasite-host system and development of clinical manifestation of the fish disease. During the disease outbreak, bacteriological indices of water indicated a high level of organic contamination and a low intensity of water self-purification processes. Clinically, the disease was manifested in $P$. scalare by decrease in appetite and motor activity, onset of ulcerative lesions of various shapes and sizes on the surface of the body and on the gill covers. Selected pure cultures of Flavobacterium columnare showed sensitivity to enrofloxacin (growth retardation zone $31.3 \pm 1.0 \mathrm{~mm}$ ); moderate resistance was found to tylosin. The microorganisms were resistant to amoxicillin, doxycycline, benzylpenicillin and tetracycline. Microscopic studies of intestinal specimens of dead $P$. scalare revealed numerous motile flagellates. It has been shown that an effective treatment regimen that provides recovery for $70 \%$ of diseased $P$. scalare is the use of enroxil $10 \%$ solution for five days, metronidazole three times a day, and "API MelaFix" for seven days. It is proved that the following measures are effective to restore the disrupted hydro-balance: periodic water replacement in the amount of $20 \%$ of the total volume, providing the aquarium with active aeration systems, planting slow-growing plants and reducing the amount of fish food provided. The measures developed were efficient, they led to elimination of the outbreak of columnaris in the $P$. scalare and to restoration of biological equilibrium in a closed aquatic ecosystem.
\end{abstract}

Keywords: Flavobacterium columnare; enrofloxacin; tylosin; metronidazole; MelaFix; enroxil; total bacterial counts.

\section{Introduction}

In the contemporary world, aquaristics is gaining in popularity and is becoming a hobby of many people. Each aquarium is a unique ecosystem, with biological balance upset causing its consequences. The most important factors that disrupt the qualitative and quantitative composition of the microbiota in water and fish are pathogens of infectious and invasive diseases (Gallani et al., 2016; Lange et al., 2018).

Among the most common diseases, a special place is occupied by columnaris, which is recognized as a serious threat to the health of both wild and cultured freshwater fish (Lange et al., 2019, 2020; Tan et al., 2019). The disease is accompanied by high mortality and causes significant losses in aquaculture (Meepagala et al., 2018; Kitiyodom et al., 2019). Complex interactions between the host, pathogen and environment have been found to affect the virulence of opportunistic microbiota (Declercq et al., 2013; Ashrafi et al., 2018).

The disease was first described by Davis (1922), who reported a large number of thin, motile bacteria isolated from fish in the Mississippi River. Gram-negative bacteria belonging to the Flavobacteriaceae family are causative agents of columnaris. The greatest losses to freshwater fish have been found to be mainly caused by three species of Flavobacterium: F. braniophilum, F. columnare and F. psychrophilum (Kumru et al., 2020). Pathogens are characterized by a high level of genetic diversity. It has been proposed to distinguish $F$. columnare isolates by four genetic groups in order to facilitate the standard nomenclature in the scientific community (LaFrentz et al., 2018). Nowadays, prospects for identification of the most common genetic groups in different aquaculture regions or industries will be promising, which will facilitate the development of more efficient control and treatment of columnaris (Zhao et al., 2016). Ravantti et al. (2019) established the complete genome sequence of the Finnish isolate in the $F$. columnare pathogen.

The causative agent of $F$. columnare is distributed worldwide in freshwater sources and is capable of affecting many different species of fish such as carp, perch and tilapia. This disease also affects many tropical freshwater aquarium fish. The $F$. columnare bacterium was isolated and identified as an etiological factor of infectious disease in Platydoras costatus. Clinical signs were typical of fish columnaris, and microscopic studies revealed numerous Gram-negative filamentous bacteria on the skin, muscle, and gill tissue of the affected fish (Tien et al., 2012).

The gram-negative $F$. columnare bacterium is an opportunistic pathogen that is manifested as a biofilm on the surfaces of the host mucous membranes, helping the pathogen resist antibacterials and disinfectants (Chowdhury \& Wakabayashi, 1990; Cai et al., 2019; Declercq et al., 2019). F. columnare infection causes skin lesions, fin erosion, and gill necrosis, causing significant mortality and economic damage in industrial fish-breeding (Baldissera et al., 2020; Tongsri et al., 2020). Recently, many researchers have been studying the pathogenesis of columnaris, which permits us to establish some features of interaction between the host and parasites (Li et al., 2017; Guo et al., 2019; Su et al., 2019). F. columnare pathogens are capable of being stored in water for some time, the duration of storage depends primarily on the chemical and physical characteristics of the aquatic environment (Chowdhury \& Wakabayashi, 
1990). Many studies on the columnaris disease indicate the need to control water quality parameters and to meet the necessary hygiene requirements for fish keeping. Studies of $F$. columnare incidence in wild and cultured freshwater fish species have shown that the bacterium usually causes disease in waters with the temperature above $25^{\circ} \mathrm{C}$. However, with the implementation of intensive fishery systems, stressed fish can also develop the disease at lower temperatures; in addition, natural water temperatures are rising to a critical level due to global warming (Varga et al., 2016).

Understanding the environmental factors contributing to the evolution of pathogens on a modern scale is a necessary factor in controlling disease outbreaks among fish (Pulkkinen et al., 2018; Sundberg et al., 2016). Studies aimed at developing efficient measures to control and preventing infectious fish diseases are also promising (Lavrinenko et al., 2015). Therefore, the purpose of our work was to develop efficient measures for elimination of columnaris in $P$. scalare common in private aquariums.

\section{Materials and methods}

Clinical-experimental studies were carried out at the Department of Infectious Pathology, Hygiene, Sanitation and Biosafety of the Poltava State Agrarian Academy.

The objects of observations were the following fish species: Pterophyllum scalare (freshwater angelfish), Puntius tetrazona (Sumatra barb), Trichopodus trichopterus (three spot gourami) Trichopodus leeri (pearl gourami), Ancistrus dolichopterus (bushymouthed catfish), which were kept in six aquariums with a capacity of $100-450 \mathrm{~L}$. The number of fish in aquariums of various sizes ranged from 16-50 specimens. The following species of algae grew in the aquariums: Nomaphila stricta, Ceratophyllum demersum, Anubias, Vallisneria, Cryptocoryne wendtii. The water was heated, the temperature was $24-27^{\circ} \mathrm{C}$. Once a month, the water in the aquarium was replaced with settled water at the same temperature. The fish were fed once a day - in the morning, using dry and frozen feed (Artemia). Aquarium lightingwais provided by fluorescent lamps (Sylvania, Germany), with Atma (China) external filters installed for water purification.

Diagnosis of fish diseases was carried out in a comprehensive manner, taking into account clinical, pathological and anatomical features and the results of microscopic and microbiological studies. Clinical studies were performed by means of conventional methods, which included a detailed medical history. During post-mortem examination of corpses, attention was paid to the position of the organs, their shape and size, the colour, texture and pattern being taken into account. The dead fish were subjected to the post-mortem and microscopic examination of intestinal specimens. Swabs made of pathological material were stained according to Gram with methylene blue solution. Primary inoculation was performed with fragments of affected skin and gill tissue of dead fish into the meat-peptone agar and cultured at $26^{\circ} \mathrm{C}$ for $24 \mathrm{~h}$. Subsequently, special nutrient media were inoculated and the pure culture obtained was identified based on morphological, cultural, tinctorial properties (Bernardet \& Bowman, 2006). The sensitivity of $F$. columnare pure culture to antibacterial drugs was studied. The disc-diffusion method was used, which included the following stages : the nutrient medium preparation, microorganisms suspensions and their inoculation, application of discs and incubation, accounting of results. Suspension of the microorganisms was prepared of 18 hour agar culture of the pathogen. Suspension in the amount of $1-2 \mathrm{~mL}$ was added onto the agar surface, distributing it evenly on the agar surface. 15 minutes after the introduction of the microorganisms' suspension onto the surface of the nutrient medium with sterile tweezers, discs with antibiotics (manufactured by "Research Center of Pharmacotherapy", Russia) were applied. Then, the plates were placed into the thermostat upside down and incubated for 18 hours at $26^{\circ} \mathrm{C}$. The microbiota's sensitivity to the following antibiotics was determined: amoxicillin $(20 \mu \mathrm{g})$, doxycycline $(30 \mu \mathrm{g})$, tylosin $(15 \mu \mathrm{g})$, enrofloxacin $(5 \mu \mathrm{g})$, tetracycline ( $30 \mu \mathrm{g})$, benzylpenicillin (10 IU). After incubation, the Petri dishes were examined and the growth retardation (bacteriostasis) zone of the microorganisms was measured in millimeters.

Separate microbiological parameters of water were also studied: the total number of bacteria at 37 and $22{ }^{\circ} \mathrm{C}$ was determined, as well as the ratio of these parameters. Water chemical parameters were determined using test system (PTERO, Ukraine), including the content of nitrates, nitrites, phosphates, iron, chlorine and $\mathrm{pH}$. Based on the studies performed a set of measures for elimination and prevention of the disease was developed. To treat the diseased fish, enroxil 10\% solution (KRKA, Slovenia) was used at a dose of $0.5 \mathrm{~mL}$ per $10 \mathrm{~L}$ of aquarium water. The drug was administered daily for five days. The active drug substance - enrofloxacin has antibacterial action against gram-positive and gram-negative microorganisms. Metranidazole (Lubnyfarm OAO, Ukraine) was also added to the aquarium water at the dose of 1 tablet $(250 \mathrm{mg})$ per $20 \mathrm{~L}$ of water, three treatments a day. The tablets were pre-dissolved in a small amount of aquarium water, then poured into the aquarium and stirred. Metronidazole belongs to nitro-5-imidazoles, its spectrum of activity includes several species of protozoa and microorganisms. "API MelaFix" (API Aquarium Pharmaceuticals, USA) was used to activate wound healing using $5 \mathrm{~mL}$ per $40 \mathrm{~L}$ of aquarium water daily for seven days. Tea tree extract based drug has antiseptic properties and promotes healing of wounds and damaged body parts in fish.

To provide the data, mean values $(\mathrm{M})$ and confidence interval for the mean were calculated. Statistical processing of absolute values was performed by conventional methods. The correlation between qualitative variables was determined using the Fisher's exact test, the difference between the means of quantitative values was assessed using the nonparametric Mann-Whitney U-test. The difference at $\mathrm{P}<0.05$ (with Bonferroni correction) was considered statistically significant.

\section{Results}

In all the studied cases, the disease onset occurred in the scalares suddenly, with the anamnesis showing that the new fish introduction into aquariums was not carried out during the last three months before the outbreaks of the disease. Clinical signs were recorded in 20-30\% of the total number of $P$. scalare specimens, other fish species (Puntius tetrazona, Trichopodus trichopterus, Trichopodus leeri, Ancistrus dolichopterus), which were kept together with them in the common aquarium, had no signs of damage. The following symptoms were initially recorded in the diseased angelfish: a decrease in appetite, which was manifested in a decrease in motor activity during feeding and a decrease in the amount of feed consumed. Individual fish, while consuming the feed, repeatedly swallowed it, then spat it out of the mouth. Gradually, they became less motile, mainly located near the surface of the water, constantly swallowing air, respiratory movements were accelerated.

In the affected specimens, the excrements acquired a mucous texture, they were hanging for a long time from the anus, having a filamentous appearance. Over the time, lesions appeared on the fins and on the surface of the body - white spots. The diameter of the lesions initially was 2 $5 \mathrm{~mm}$, and after a few days it increased rapidly, reaching the size of 1$2 \mathrm{~cm}$ (Fig. 1). Ulcerative lesions of the skin led to the loss in a large part of the epidermis, sometimes the affected areas of the fish body acquired a reddish colour due to the muscle tissue exposure (Fig. 2). Within three or four days, angelfish with a large area of injuries perished.

In some specimens, the disease was initially manifested by the redness of the skin near the mouth, as well as on the gill covers. Later on, ulcers of various sizes and shapes (Fig. 3) were formed at this place, which eventually turned into perforation cavities. The oral cavity of the fish was thus deformed, making it difficult or impossible to receive feed (Fig. 4). Such a course usually lasted for a week and ended in death.

During the first seven days of the disease, $40 \%$ of the diseased specimens perished. During post-mortem examination, gill filaments darkening was recorded in the angelfish, they lost elasticity and were easily lacerated. Microscopic studies were performed on crushed intestinal specimens of the dead fish, during which a significant number of flagellates were found, which moved quickly and erratically. Specific identification of protozoa was not performed. During the initial inoculation, which was carried out with fragments of the affected skin and gill tissue of the dead fish, small round transparent colonies grew on meat-and-peptone agar. Later they grew muddy and acquired creamy colour. Re-inoculations were made in a special nutrient medium to isolate a pure culture and to identify the cultures obtained, which permitted us to establish the etiological factor that caused the disease among the angelfish, namely $F$. columnare. 


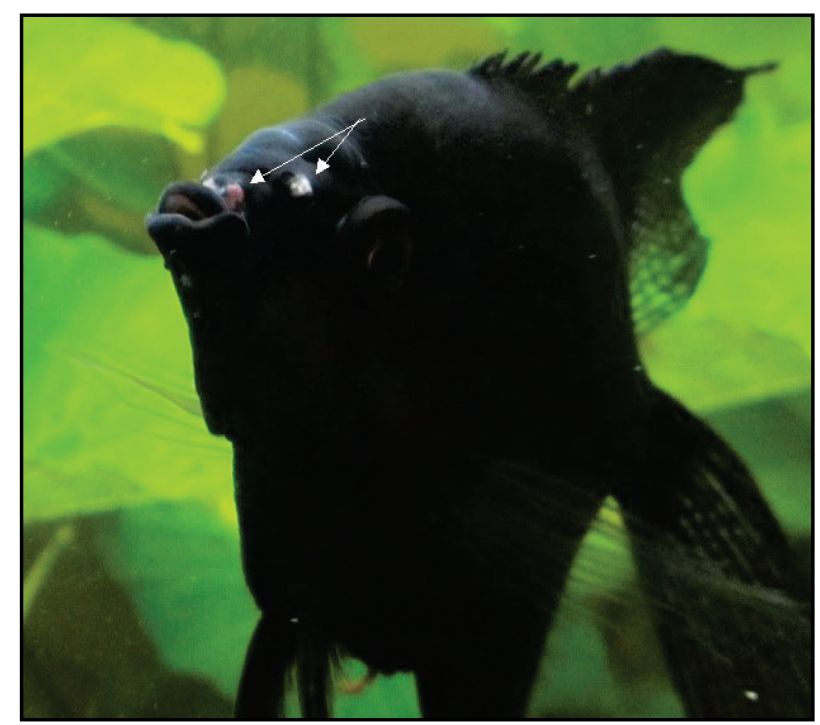

Fig. 1. Small white spots on surfaces of Pterophyllum scalare

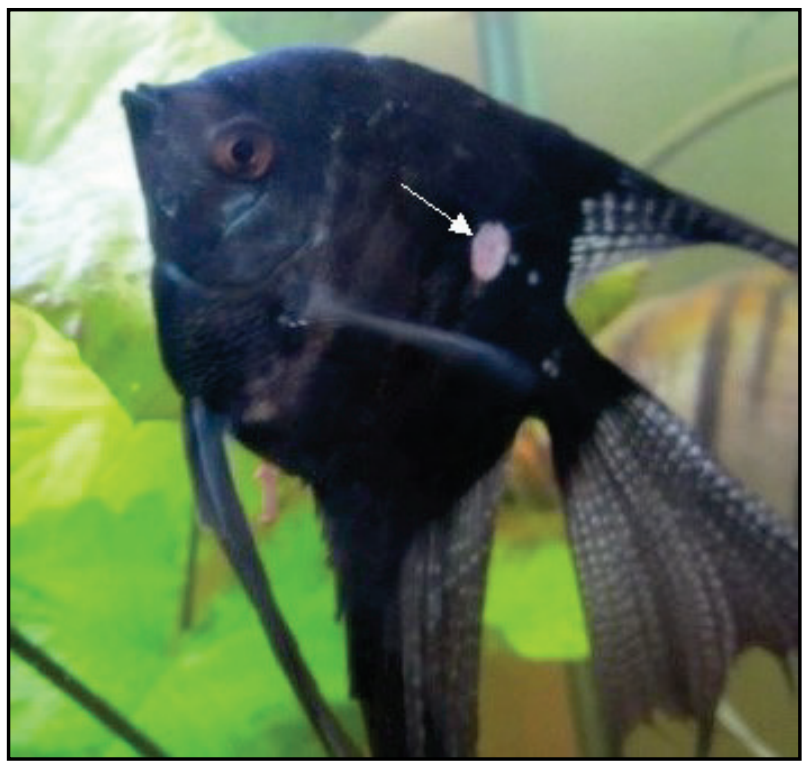

Fig. 2. Skin lesions and muscle tissue exposure on the lateral surface of Pterophyllum scalare

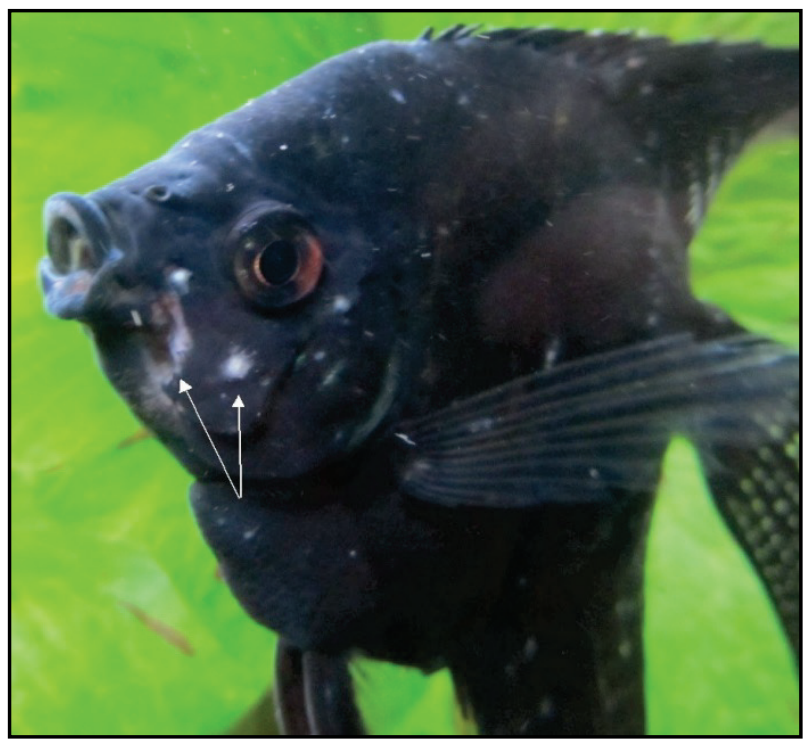

Fig. 3. Ulcers of various sizes and shapes near the oral cavity and on the gill cover of Pterophyllum scalare

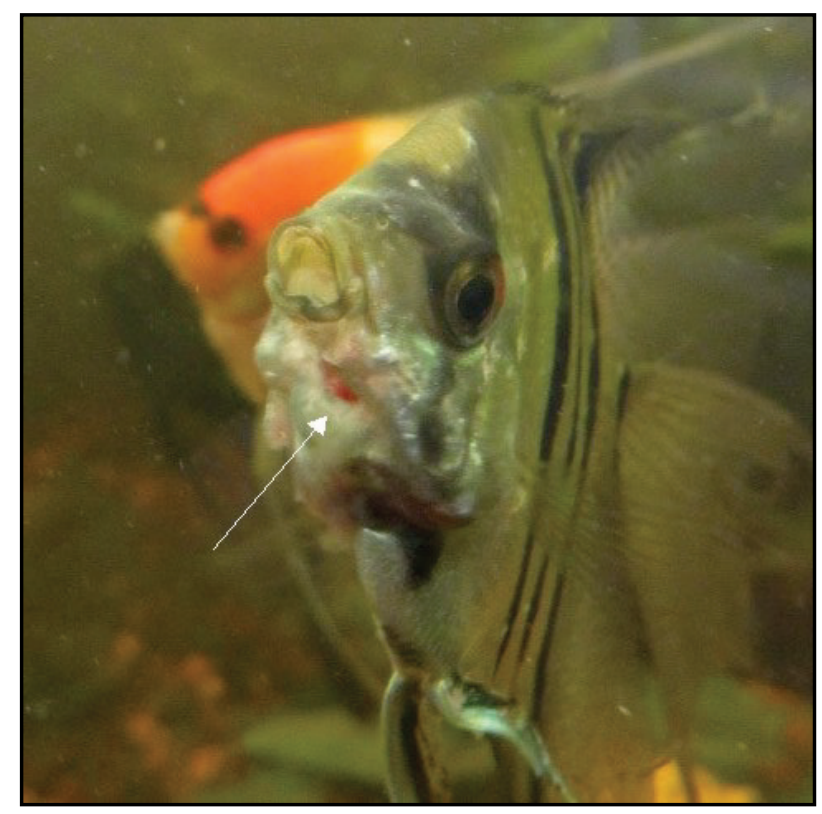

Fig. 4. Formation of perforation cavities under the mouth of Pterophyllum scalare

Microscopic study of the $F$. columnare pathogen's pure culture revealed long, thin sticks. The bacteria aggregations formed columns, which frequently acquired a domed shape. For the most part, rod-shaped bacteria formed conglomerates: long separate chains or clusters in the form of "hay" (Fig. 5).

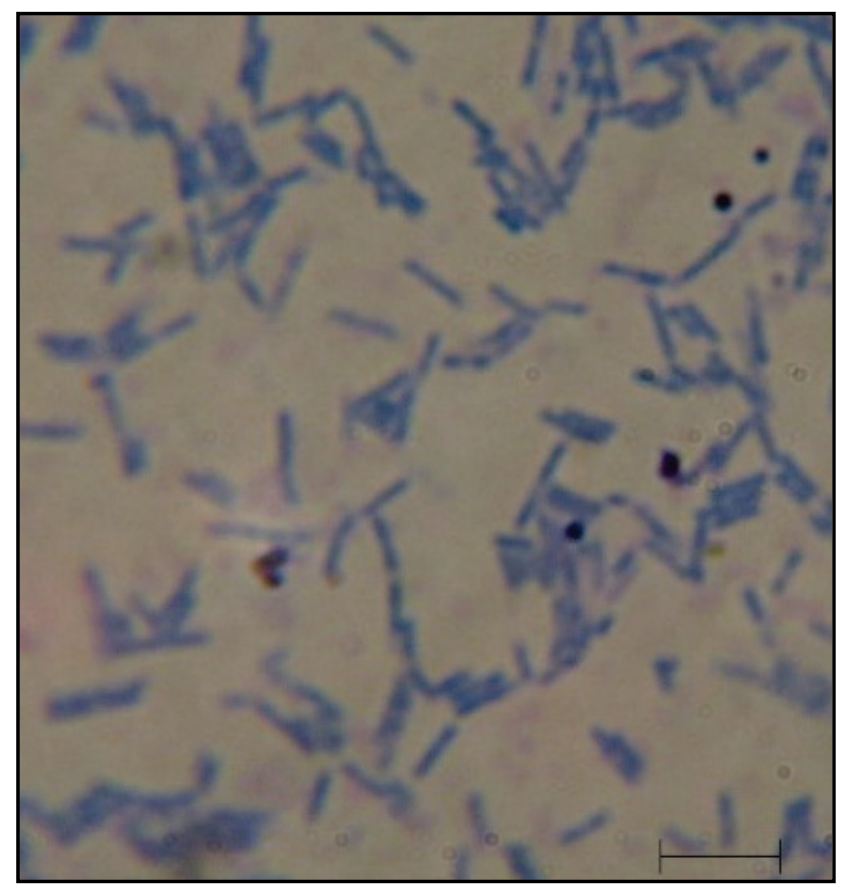

Fig. 5. Causative agent of Flavobacterium columnare stained with methylene blue: $b a r=10 \mu \mathrm{m}$

Later on, sensitivity of $F$. columnare pure cultures to the following antibacterial preparations was studied: amoxicillin $(20 \mu \mathrm{g})$, doxycycline $(30 \mu \mathrm{g})$, tylosin $(15 \mu \mathrm{g})$, enrofloxacin $(5 \mu \mathrm{g})$, tetracycline $(30 \mu \mathrm{g})$, benzylpenicillin (10 IU). The results of assessing the sensitivity of isolated microflora to individual antibiotics are shown in Table 1.

According to the results obtained, cultures of $F$. columnare showed sensitivity to enrofloxacin (Fig. 6). This antibiotic at a concentration of $5 \mu \mathrm{g}$ caused the microbiota bacteriostasis zone of $31.3 \pm 1.0 \mathrm{~mm}$. Moderate resistance to tylosin was established with $13.3 \pm 0.2 \mathrm{~mm}$. The microorganisms were resistant to amoxicillin, doxycycline, benzylpenicillin and tetracycline. 
Table 1

Sensitivity of the isolated microflora to individual antibiotics

\begin{tabular}{lcc}
\hline \multicolumn{1}{c}{ Name of the drug } & Bacteriostasis zone, $\mathrm{mm}$ & Sensitivity categories \\
\hline Amoxicillin & $6.25 \pm 0.42$ & resistant \\
Doxycycline & $7.75 \pm 0.20$ & resistant \\
Benzylpenicillin & $5.25 \pm 0.14$ & resistant \\
Enrofloxacin & $31.25 \pm 1.02$ & sensitive \\
Tetracycline & $3.50 \pm 0.18$ & resistant \\
Tylosin & $13.25 \pm 0.20$ & moderately resistant \\
\hline
\end{tabular}

Due to the existence of fish in a closed aquatic ecosystem, it is impractical to consider any infectious disease, including columnaris, as only a problem for diseased fish. Water is a natural habitat for hydrobionts and most infectious diseases develop in the event of the eco-balance disturbance, resulting in the activation of opportunistic microbiota. Therefore, it is not enough to treat only diseased individuals without taking into account changes in the hydrochemical regime and disturbance of the aquarium ecosystem balance.

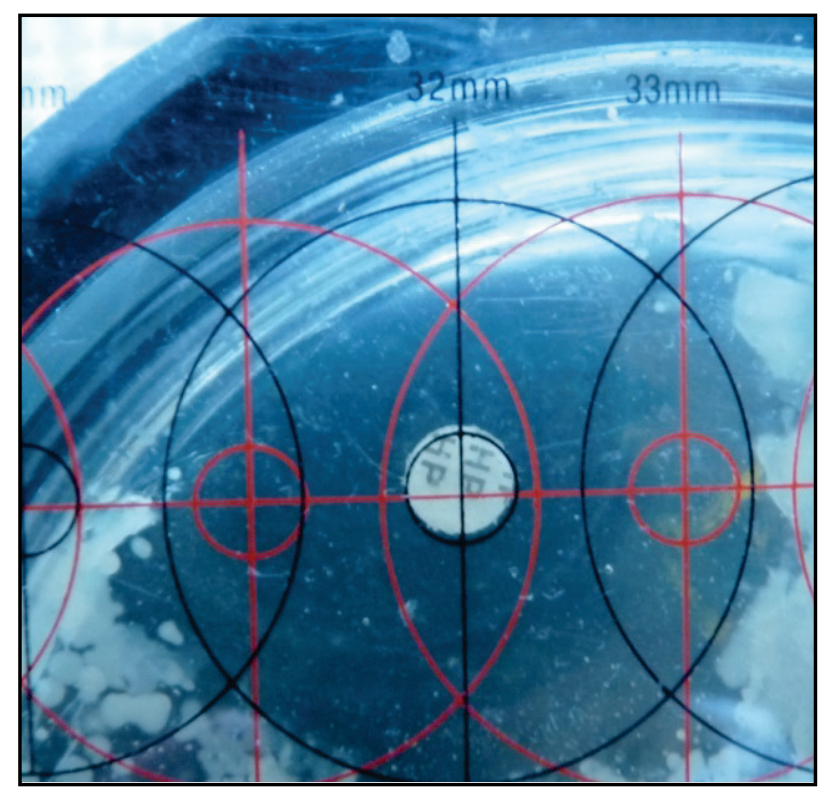

Fig. 6. Determination of Flavobacterium columnare sensitivity to enrofloxacin

To determine changes in the hydrochemical regime, a study of aquarium water was carried out. The chemical characteristics of aquarium water during the outbreak of columnaris were as follows: nitrate content $15.0 \pm 1.2 \mathrm{mg} / \mathrm{L}$, nitrite $-0.1 \pm 0.02 \mathrm{mg} / \mathrm{L}$, phosphate $-5.0 \pm 0.8 \mathrm{mg} / \mathrm{L}$, $\mathrm{pH}-8.0 \pm 0.5$, iron content $-0.1 \pm 0.01 \mathrm{mg} / \mathrm{L}$, ammonia and residual chlorine were not detected. The data obtained indicate the alkaline reaction of the water, which is a favourable factor for the existence and reproduction of columnaris pathogens. Nitrite and nitrate levels were within the normal range but the phosphate content was exceeded. Such indices can be the result of fish over-feeding when unused food residues decompose to form phosphates.

In addition to studying the hydrochemical regime, we performed a study of the water's bacteriological indices (Fig. 7). The total bacterial number at an incubation temperature of $37^{\circ} \mathrm{C}$ characterizes the indicator group of microorganisms (allochthonous microbiota). This index was $1.9 \pm 0.4$ thousand $\mathrm{CFU} / \mathrm{mL}$. The total bacterial number at an incubation temperature of $22{ }^{\circ} \mathrm{C}$ characterizes the indicator group of microorganisms in saprophytic (autochthonous) aquatic microbiota, it was $2.4 \pm 0.5$ thousand CFU $/ \mathrm{mL}$. The ratio was $1.3 \pm 0.1$, lower than the normative value for a balanced aquatic ecosystem, which indicates the low intensity of water self-purification processes. It is probable that fish disease has arisen against the background of adverse changes in the chemical composition and microbiocenosis of the aquarium water. High alkalinity and excess of phosphates compared to the norm provoked accumulation of opportunistic microbiota, resulting in a dysequilibrium in the parasite-host system and in development of the fish disease clinical manifestation.
As our research shows that the water in the aquarium had an alkaline reaction with a high content of phosphates, every other day within two weeks $20 \%$ of the aquarium water volume was changed, using filtered and remineralized water, the water aeration being ensured. To reduce the level of phosphates, slow-growing plants, such as Echinodorus aspersus, E. bleheri, E. verticalis, were planted, and fish daily food consumption was reduced.

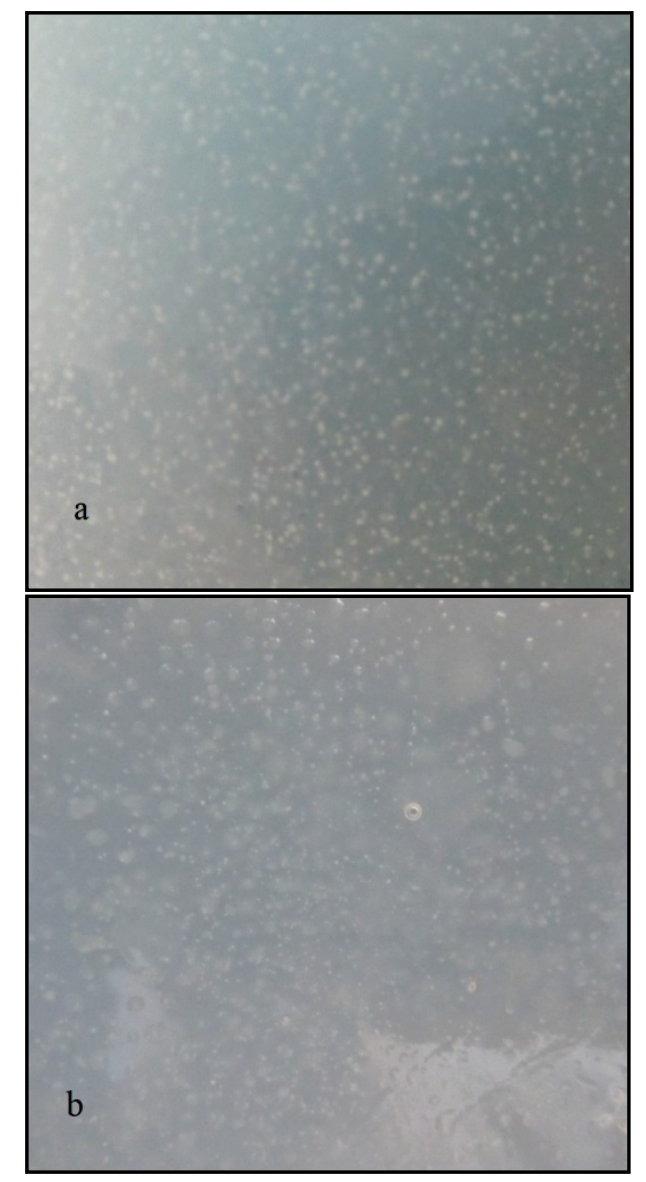

Fig. 7. Determination of the aquarium water bacteriological indices: $a$ - the total bacterial number at an incubation temperature of $22^{\circ} \mathrm{C}$, $b$ - the total bacterial number at an incubation temperature of $37^{\circ} \mathrm{C}$

As a result of the treatment, a gradual healing of skin lesions and recovery of $70 \%$ of fish with signs of skin injuries were recorded. A month later bacteriological studies of aquarium water were carried out: the total bacterial number at $37^{\circ} \mathrm{C}$ was $0.3 \pm 0.02$ thousand $\mathrm{CFU} / \mathrm{mL}$, at $22^{\circ} \mathrm{C}-$ $1.1 \pm 0.12$ thousand $\mathrm{CFU} / \mathrm{mL}$, and the ratio was $4.0 \pm 0.6$. The phosphate content was $1.5 \pm 0.5 \mathrm{mg} / \mathrm{L}$, the $\mathrm{pH}$ was $7.0 \pm 0.5$. These indices meet the normative values for a balanced aquatic ecosystem. Over the next two months, no new cases of the angelfish disease were detected. Thus, the measures performed permitted us to eliminate the outbreak of columnaris in the aquarium fish and to restore biological equilibrium in the conditions of a closed aquarium ecosystem.

\section{Discussion}

Columnaris is a serious bacterial disease that causes significant mortality in many freshwater fish species (Faisal et al., 2017; Li et al., 2017; Baldissera et al., 2020). Representatives of the Spironucleus and Hexamita genera inhabit the digestive tract in a variety of host animals, may be pathogens or commensals (Jørgensen \& Sterud, 2007; Gallani et al., 2016). Our studies have found that columnaris in the angelfish intestine reveals a significant number of flagellates, which are likely to complicate the course of the infection. Studies by Louhi et al. (2015) found that coinfection promotes more virulent parasite genotypes through increased competition for the host's resources. The lethality from $F$. columnare infection has been proven to be higher in fish, against the background of parasitic inva- 
sion (Roon et al., 2015). There are many reports in the literature about the treatment of columnaris in various fish species (Mohammed \& Arias, 2015; Xu et al., 2016; Chen et al., 2020). One of the treatment approaches is to use antibacterial drugs. However, a negative aspect of antibiotic use in agriculture is the potential development of antibiotic-resistant bacteria (Sundberg \& Karvonen, 2018). It is therefore recommended to use environmentally friendly natural compounds for treatment of fish.

Plant extracts of Terminalia brownii, platanosides extracted from the leaves of the Platanus occidentalis tree, have been proven to be promising for the treatment of columnaris (Schrader et al., 2015; Schrader et al., 2016). Agaricus bisporus supplement has been found to enhance a nonspecific immune response that will reduce the mortality from $F$. columnare infection (Harikrishnan et al., 2018). Dietary supplements with probiotics can provide protection extending beyond the intestine to the skin and gills surface (Zhao et al., 2015; Wang et al., 2020).

However, in aquarium fishery the use of antibacterial drugs is often recommended to treat diseases of bacterial etiology (Lavrinenko et al., 2015). Studies by Varga et al. (2016) found that isolates of the columnaris pathogen had multilevel resistance to many antibacterial drugs: they all were resistant to ampicillin and polymyxin $\mathrm{B}$, cotrimoxazole, $88 \%$ were resistant to gentamicin and $72 \%$ - to chloramphenicol. Most isolates were sensitive to erythromycin ( $88 \%$ ), furazolidone (76\%) and florfenicol (68\%).

Our studies found that $F$. columnare cultures isolated from diseased angelfish showed a sensitivity to enrofloxacin, a moderate sensitivity to tylosin. The isolated strains were resistant to amoxicillin, doxycycline, benzylpenicillin and tetracycline. Therefore, enroxil 10\% solution (KRKA, Slovenia), the active substance of which is enrofloxacin, was used for the integrated treatment. As microscopic studies in the dead fish intestine revealed a significant number of flagellates, metranidazole (Lubnyfarm $\mathrm{OAO}$, Ukraine) was also used. As a result of the integrated treatment, $70 \%$ of fish diseased with columnaris were reported to have recovered.

\section{Conclusions}

It has been established that aquarium fish columnaris arose against the background of adverse changes in the chemical composition and microbiocenosis of aquarium water. High alkalinity $(8.0 \pm 0.06)$ and significant phosphate level $(5.0 \pm 0.8 \mathrm{mg} / \mathrm{L})$, compared to the norm, provoked accumulation of microbiota. During the outbreak of the disease, the total bacterial number of aquarium water at $37{ }^{\circ} \mathrm{C}$ was $1.9 \pm 0.4$ thousand $\mathrm{CFU} / \mathrm{mL}$, at $22^{\circ} \mathrm{C}-2.4 \pm 0.5$ thousand $\mathrm{CFU} / \mathrm{mL}$, and their ratio was $1.3 \pm 0.1$, which is an evidence of organic pollution and low intensity of water self-purification processes. $F$. columnare cultures isolated from dead angelfish showed sensitivity to enrofloxacin (bacteriostasis zone $31.3 \pm 1.0 \mathrm{~mm}$ ); moderate resistance to tylosin $(13.3 \pm 0.2 \mathrm{~mm})$. The microorganisms were resistant to amoxicillin, doxycycline, benzylpenicillin and tetracycline.

High efficacy of the integrated treatment was established, which included the use of drugs: enroxil 10\% solution (KRKA, Slovenia) for five days, metranidazole (Lubnyfarm OAO, Ukraine) three treatments every other day and "API MelaFix" (API Aquarium Pharmaceuticals, USA) daily for seven days. The integrated treatment provided recovery for $70 \%$ the diseased angelfish. It is proved that to restore the disturbed balance, efficient measures are systematic replacement of water, its active aeration, planting of slowly growing aquatic plants and reducing the amount of feed consumption in fish. The integrated treatment of aquarium fish columnaris permitted us to eliminate the outbreak of the disease and to restore biological equilibrium in the conditions of a closed aquarium ecosystem.

One month after the measures taken, the total bacterial number of water at $37{ }^{\circ} \mathrm{C}$ was $0.30 \pm 0.02$ thousand $\mathrm{CFU} / \mathrm{mL}$, at $22^{\circ} \mathrm{C}-1.10 \pm 0.12$ thousand $\mathrm{CFU} / \mathrm{mL}$, and the ratio was $4.0 \pm 0.6$. The phosphate content was $1.5 \pm 0.5 \mathrm{mg} / \mathrm{L}$, the $\mathrm{pH}$ was $7.0 \pm 0.5$. These indices meet the normative values for a balanced aquatic ecosystem. For prevention of aquarium fish columnaris, it is necessary to: ensure optimal existence conditions for all aquatic organisms, control the basic parameters of the hydrochemical regime, organize proper and varied feeding. When catching and transplanting, one should not allow fish to be injured, transplanted fish must be only taken from aquariums that are safe from infectious diseases. It is necessary to daily carry out a set of measures aimed at maintaining the proper sanitary condition: to remove unused food, dead parts of plants, corpses of fish, shell-fish, prevent overpopulation of the aquarium and its significant overgrowth with aquatic vegetation.

\section{References}

Ashrafi, R., Bruneaux, M., Sundberg, L. R., Pulkkinen, K., Valkonen, J., \& Ketola, T. (2018). Broad thermal tolerance is negatively correlated with virulence in an opportunistic bacterial pathogen. Evolutionary Applications, 11(9), $1700-1714$.

Baldissera, M. D., Souza, C. F., Dias, J. B., Da Silva, T. O., Tavares, G. C., Valladão, G. M. R., da Silva, A. S., Verdi, C. M., Santos, R. C. V., Vencato, M., da Veiga, M. L., da Rocha, M., Cunha, M. A., \& Baldisserotto, B. (2020). Branchial bioenergetics dysfunction as a relevant pathophysiological mechanism in freshwater silver catfish (Rhamdia quelen) experimentally infected with Flavobacterium columnare. Microbial Pathogenesis, 138, 103817.

Bernardet, J. F., \& Bowman, J. P. (2006). The genus Flavobacterium. In: Dworkin, M. (Ed.). The Prokaryotes: A handbook on the biology of bacteria. New York, Springer. Pp. 481-531

Cai, W., De La Fuente, L., \& Arias, C. R. (2019). Transcriptome analysis of the fish pathogen Flavobacterium columnare in biofilm suggests calcium role in pathogenesis. BMC Microbiology, 19, 151.

Chen, T., Zhou, J., Qu, Z., Zou, Q., Liu, X., Su, J., Fu, X., \& Yuan, G. (2020). Administration of dietary recombinant hepcidin on grass carp (Ctenopharyngodon idella) against Flavobacterium columnare infection under cage aquaculture conditions. Fish and Shellfish Immunology, 99, 27-34

Chowdhury, M. B. R., \& Wakabayashi, H. (1990). Survival of four major bacterial fish pathogens in different types of experimental water. Bangladesh Journal of Microbiology, 7, 47-54.

Davis, H. S. (1922). A new bacterial disease in freshwater fishes. United States Bureau of Fisheries Bulletin, 38, 37-63.

Declercq, A. M., Cai, W., Naranjo, E., Thongda, W., Eeckhaut, V., Bauwens, E., Arias, C., De La Fuente, L., Beck, B. H., Lange, M. D., Peatman, E., Haesebrouck, F., Aerts, J., \& Decostere, A. (2019). Evidence that the stress hormone cortisol regulates biofilm formation differently among Flavobacterium columnare isolates. Veterinary Research, 50, 24.

Declercq, A. M., Haesebrouck, F., Van den Broeck, W., Bossier, P., \& Decostere, A. (2013). Columnaris disease in fish: A review with emphasis on bacterium-host interactions. Veterinary Research, 44, 27.

Faisal, M., Diamanka, A., Loch, T. P., LaFrentz, B. R., Winters, A. D., García, J. C., \& Toguebaye, B. S. (2017). Isolation and characterization of Flavobacterium columnare strains infecting fishes inhabiting the Laurentian Great Lakes basin. Journal of Fish Diseases, 40(5), 637-648.

Gallani, S. U., Sebastião, F. A., Valladão, G. M. R., Boaratti, A. Z., \& Pilarski, F. (2016). Pathogenesis of mixed infection by Spironucleus sp. and Citrobacter freundii in freshwater angelfish Pterophyllum scalare. Microbial Pathogenesis, 100, 119-123.

Guo, Q., Zheng, H., Liu, X., Chi, S., Xu, Z., \& Wang, Q. (2019). Nutrient sensing signaling functions as the sensor and regulator of immunometabolic changes in grass carp during Flavobacterium columnare infection. Fish and Shellfish Immunology, 93, 278-287.

Harikrishnan, R., Naafar, A., Musthafa, M. S., Ahamed, A., Arif, I. A., \& Balasundaram, C. (2018). Effect of Agaricus bisporus enriched diet on growth, hematology, and immune protection in Clarias gariepinus against Flavobacterium columnare. Fish and Shellfish Immunology, 73, 245-251.

Jørgensen, A., \& Sterud, E. (2007). Phylogeny of spironucleus (Eopharyngia: Diplomonadida: Hexamitinae). Protist, 158(2), 247-254.

Kitiyodom, S., Yata, T., Yostawornkul, J., Kaewmalun, S., Nittayasut, N., Suktham, K., Surassmo, S., Namdee, K., Rodkhum, C., \& Pirarat, N. (2019). Enhanced efficacy of immersion vaccination in tilapia against columnaris disease by chitosan-coated "pathogen-like" mucoadhesive nanovaccines. Fish and Shellfish Immunology, 95, 213-219.

Kumru, S., Tekedar, H. C., Blom, J., Lawrence, M. L., \& Karsi, A. (2020). Genomic diversity in flavobacterial pathogens of aquatic origin. Microbial Pathogenesis, 10, 104053.

LaFrentz, B. R., García, J. C., Waldbieser, G. C., Evenhuis, J. P., Loch, T. P., Liles, M. R., Wong, F. S., \& Chang, S. F. (2018). Identification of four distinct phylogenetic groups in Flavobacterium columnare with fish host associations. Frontiers in Microbiology, 9, 452.

Lange, M. D., Abernathy, J., \& Farmer, B. D. (2019). Evaluation of a recombinant Flavobacterium columnare DnaK protein vaccine as a means of protection against columnaris disease in channel catfish (Ictalurus punctatus). Frontiers in Immunology, 10, 1175.

Lange, M. D., Farmer, B. D., \& Abernathy, J. (2018). Catfish mucus alters the Flavobacterium columnare transcriptome. FEMS Microbiology Letters, $365(22)$, fny 244 . 
Lange, M. D., Farmer, B. D., \& Abernathy, J. (2020). Vertebrate mucus stimulates biofilm development and upregulates iron acquisition genes in Flavobacterium columnare. Journal of Fish Diseases, 43(1), 101-110.

Lavrinenko, I. V., Peredera, O. O., \& Zhernosik, I. A. (2015). Osoblyvosti klinichnoho perebihu kolumnariozu skaliarii [Characteristics of clinical course of columnaris disease in angelfish]. Scientific Messenger of Lviv National University of Veterinary Medicine and Biotechnologies named after S. Z. Gzhytskyj, 17(2), 112-118 (in Ukrainian).

Lavrinenko, I. V., Peredera, O. O., \& Zhernosik, I. A. (2015). Zahody borot'by z kolumnariozom skaljarij [Measures and prophylaxis against columnaris disease in angelfish]. Bulletin of Sumy National Agrarian University, 37, 153-155 (in Ukrainian).

Li, N., Zhu, Y., LaFrentz, B. R., Evenhuis, J. P., Hunnicutt, D. W., Conrad, R. A., Barbier, P., Gullstrand, C. W., Roets, J. E., Powers, J. L., Kulkarni, S. S., Erbes, D. H., García, J. C., Nie, P., \& McBride, M. J. (2017). The type IX secretion system is required for virulence of the fish pathogen Flavobacterium columnare. Applied Environmental Microbiology, 83(23), e01769-17.

Louhi, K. R., Sundberg, L. R., Jokela, J., \& Karvonen, A. I. (2015). Interactions among bacterial strains and fluke genotypes shape virulence of co-infection. Proceedings of the Royal Society B: Biological Sciences, 282, 20152097.

Meepagala, K. M., \& Schrader, K. K. (2018). Antibacterial activity of constituents from mangosteen Garcinia mangostana fruit pericarp against several channel catfish pathogens. Journal of Aquatic Animal Health, 30(3), 179-184.

Mohammed, H. H., \& Arias, C. R. (2015). Potassium permanganate elicits a shift of the external fish microbiome and increases host susceptibility to columnaris disease. Veterinary Research, 46, 82.

Pulkkinen, K., Pekkala, N., Ashrafi, R., Hämäläinen, D. M., Nkembeng, A. N., Lipponen, A., Hiltunen, T., Valkonen, J. K., \& Taskinen, J. (2018). Effect of resource availability on evolution of virulence and competition in an environmentally transmitted pathogen. FEMS Microbiology Ecology, 94(5), fiy060.

Ravantti, J. J., Laanto, E., Papponen, P., \& Sundberg, L. R. (2019). Complete genome sequence of fish pathogen Flavobacterium columnare strain B185, originating from Finland. Microbiology Resource Announce, 8(49), e01285-19.

Roon, S. R., Alexander, J. D., Jacobson, K. C., \& Bartholomew, J. L. (2015). Effect of Nanophyetus salmincola and bacterial co-infection on mortality of juvenile chinook salmon. Journal of Aquatic Animal Health, 27(4), 209-216.

Schrader, K. K., Cantrell, C. L., Midiwo, J. O., \& Muhammad, I. (2016). Compounds from Terminalli brownii extracts with toxicity against the fish pathogenic bacterium Flavobacterium columnare. Natural Product Communications, 11(11), 1679-1682.

Schrader, K. K., Hamann, M. T., McChesney, J. D., Rodenburg, D. L., \& Ibrahim, M. A. (2015). Antibacterial activities of metabolites from Platanus occidentalis (american sycamore) against fish pathogenic bacteria. Aquaculture Research and Development, 6(10), 1000364.
Su, L., Xu, C., Cai, L., Qiu, N., Hou, M., \& Wang, J. (2019). Susceptibility and immune responses after challenge with Flavobacterium columnare and Pseudomonas fluorescens in conventional and specific pathogen-free rare minnow (Gobiocypris rarus). Fish and Shellfish Immunology, 98, 875-886.

Sundberg, L. R., \& Karvonen, A. (2018). Minor environmental concentrations of antibiotics can modify bacterial virulence in co-infection with a non-targeted parasite. Biology Letters, 14, 20180663.

Sundberg, L. R., Ketola, T., Laanto, E., Kinnula, H., Bamford, J. K., Penttinen, R. \& Mappes, J. (2016). Intensive aquaculture selects for increased virulence and interference competition in bacteria. Proceedings of the Royal Society B: Biological Sciences, 283, 20153069.

Tan, S., Wang, W., Tian, C., Niu, D., Zhou, T., Yang, Y., Gao, D., \& Liu, Z. (2019). Post-transcriptional regulation through alternative splicing after infection with Flavobacterium columnare in channel catfish (Ictalurus punctatus) Fish and Shellfish Immunology, 91, 188-193.

Tien, N. T., Dung, T. T., Tuan, N. A., \& Crumlish, M. (2012). First identification of Flavobacterium columnare infection in farmed freshwater striped catfish Pangasianodon hypophthalmus. Diseases of Aquatic Organisms, 100(1), 83-88.

Tongsri, P., Meng, K., Liu, X., Wu, Z., Yin, G., Wang, Q., Liu, M., \& Xu, Z (2020). The predominant role of mucosal immunoglobulin IgT in the gills of rainbow trout (Oncorhynchus mykiss) after infection with Flavobacterium columnare. Fish and Shellfish Immunology, 99, 654-662.

Varga, Z., Sellyei, B., Paulus, P., Papp, M., Molnár, K., \& Székely, C. (2016). Isolation and characterisation of flavobacteria from wild and cultured freshwater fish species in Hungary. Acta Veterinaria Hungarica, 64(1), 13-25.

Wang, Q., Shen, J., Yan, Z., Xiang, X., Mu, R., Zhu, P., Yao, Y., Zhu, F., Chen, K., Chi, S., Zhang, L., Yu, Y., Ai, T., Xu, Z., \& Wang, Q. (2020). Dietary Glycyrrhiza uralensis extracts supplementation elevated growth performance, immune responses and disease resistance against Flavobacterium columnare in yellow catfish (Pelteobagrus fulvidraco). Fish and Shellfish Immunology, 97, 153-164.

Xu, J., Feng, L., Jiang, W. D., Wu, P., Liu, Y., Jiang, J., Kuang, S. Y., Tang, L., Tang, W. N., Zhang, Y. A., \& Zhou, X. Q. (2016). Effects of dietary protein levels on the disease resistance, immune function and physical barrier function in the gill of grass carp (Ctenopharyngodon idella) after challenged with Flavobacterium columnare. Fish and Shellfish Immunology, 57, 1-16.

Zhao, H., Li, C., Beck, B. H., Zhang, R., Thongda, W., Davis, D. A., \& Peatman, E. (2015). Impact of feed additives on surface mucosal health and columnaris susceptibility in channel catfish fingerlings, Ictalurus punctatus. Fish and Shellfish Immunology, 46(2), 624-637.

Zhao, L., Tu, J., Zhang, Y., Wang, J., Yang, L., Wang, W., Wu, Z., Meng, Q., \& Lin, L. (2016). Transcriptomic analysis of the head kidney of topmouth culter (Culter alburnus) infected with Flavobacterium columnare with an emphasis on phagosome pathway. Fish and Shellfish Immunology, 57, 413-418. 